\title{
Panduan Mini Manajemen SDM yang Esensial
}

\section{Widji Lailatur Rochmah}

\author{
Universitas Nahdlatul Ulama Sidoarjo \\ widji@protonmail.com
}

\begin{abstract}
Manajemen sumber daya manusia (SDM) atau Human resource (HR) yang efektif mencegah anarki di seluruh perusahaan. Dari menyelesaikan perselisihan internal, hingga menghadirkan persatuan bagi pelanggan, hingga sekadar patuh pada hukum, manajemen SDM adalah disiplin vital yang terlalu sering digeneralisasi dan dikeluarkan dari pikiran.
\end{abstract}

Manajemen Sumber Daya Manusia adalah tanggung jawab untuk produktivitas dan hubungan konstruktif organisasi dengan karyawannya (Purnomo, Putri, \& Rosyidah, 2017). Manajemen Sumber Daya Manusia digunakan sebagai penunjang untuk meningkatkan perekonomian (Asitah et al., 2018). Pengalaman dan keberhasilan menunjukkan manajemen SDM berperan bagi organisasi (Nahdiyah et al., 2017). Itu sebabnya kajian ini akan membahas beberapa 
tips manajemen SDM untuk membantu menjaga karyawan tetap aktif dan perusahaan berjalan dengan lancar. Teruslah membaca untuk mempelajari semua yang perlu diketahui untuk menghindari kesalahan manajemen SDM.

\section{Kompartementalisasi}

Kompartementalisasi

adalah

keterampilan yang memungkinkan Anda untuk menempatkan pekerjaan Anda ke dalam satu kotak dan sisa hidup Anda ke dalam yang lain, dan tidak pernah keduanya bertemu. Anda tidak perlu membuat perpecahan menjadi parah, tetapi Anda perlu memisahkan pekerjaan dan kehidupan rumah jika Anda ingin berhasil dalam SDM. Mengapa? Karena masalah SDM tidak pernah berakhir. Anda tidak akan pernah memiliki hari ketika Anda bisa mengatakan, "Saya sudah selesai. Semua karyawan senang. Semua kebijakan dan prosedur mematuhi. Semua manajer telah mendapatkan pelatihan yang tepat. Dan semua orang bergaul dengan indah. "Itu tidak akan pernah terjadi. Anda akan membutuhkan kemampuan untuk pulang dan tidak memikirkan pekerjaan atau Anda akan menjadi gila (Lucas, 2019). 


\section{Berkomunikasi secara teratur}

Komunikasi sangat penting dalam setiap profesi, tetapi khususnya dalam manajemen SDM. Anda perlu menyentuh basis secara teratur dengan tim Anda dan anggota perusahaan lainnya untuk mengawasi semuanya dan memastikan seluruh operasi tetap pada jalurnya. Sekali lagi, ini adalah salah satu tip manajemen SDM yang lebih mendasar. Memiliki hubungan yang kuat dengan orang lain melalui pertemuan rutin dan kebijakan pintu terbuka untuk komunikasi dan umpan balik sangat penting untuk mengetahui di mana (dan siapa) yang perlu Anda fokuskan (Mulholland, 2017).

\section{Menciptakan Organisasi yang Egaliter}

Praktik terbaik dalam manajemen SDM ini berakar pada praktik egaliter manajemen Jepang. Meskipun kami baru saja melihat bahwa beberapa karyawan lebih kritis daripada yang lain untuk keberhasilan organisasi, ini tidak boleh dikomunikasikan sedemikian rupa. Setiap karyawan adalah anggota organisasi yang berharga dan harus diperlakukan seperti itu. Dalam organisasi Jepang, ini dinyatakan dengan kantin umum, seragam perusahaan, dan penyakit serupa serta hak liburan. Budaya 
egaliter seperti itu menunjukkan bahwa setiap orang berhak mendapatkan penghargaan yang sama dan dapat membantu dalam mempromosikan berbagi ide (Vulpen, 2018).

\section{Pelajari Bagaimana Bisnis Beroperasi untuk Melihat Gambaran yang Lebih Besar}

Semakin banyak yang Anda ketahui tentang bagaimana setiap orang berinteraksi satu sama lain, metrik keberhasilan masingmasing tim, dan bagaimana satu tim memengaruhi yang lain, semakin mudah untuk melihat gambaran yang lebih besar dan memperhitungkannya ketika membuat keputusan besar. Dengan mempelajari seluk beluk tentang bagaimana bisnis beroperasi secara keseluruhan dan bagaimana masingmasing tim memengaruhi yang lain, Anda dapat lebih mudah melihat penyebab setiap masalah dan sampai ke akar masalahnya lebih cepat. Tidak hanya itu, tetapi pengetahuan ini kemudian memungkinkan Anda memprediksi efek dari masalah yang muncul di tim tertentu (misalnya, seseorang diberhentikan, berhenti, sakit atau sedang berlibur, dll). Apakah Anda harus mengalihkan sumber daya untuk menjelaskan masalah ini atau memberikan pelatihan tambahan untuk membiarkan orang 
lain mengambil tugas baru, Anda akan tahu tindakan terbaik yang harus diambil dan ke mana harus memfokuskan upaya Anda. Selain itu, mengetahui bagaimana elemen bisnis dan keuangan di dalamnya beroperasi memungkinkan Anda memberikan ukuran kinerja nyata kepada karyawan. Salah satu cara terbaik untuk memotivasi karyawan adalah menunjukkan kepada mereka bagaimana bisnis berjalan secara keseluruhan, dan bagaimana mereka berkontribusi terhadap hal itu, yang bisa sulit dilakukan jika Anda tidak mengetahui bagaimana tugas mereka sesuai dengan gambaran yang lebih besar (Mulholland, 2017).

\section{Memahami Bisnis}

Sulit untuk memanfaatkan modal manusia kecuali Anda memiliki pemahaman yang lengkap tentang bisnis ini. Ini berarti mengidentifikasi pemangku kepentingan masing-masing yaitu manajemen puncak, karyawan, karyawan potensial, dan semua orang yang berada di bawah payung perusahaan. Pahami kebutuhan dan kebutuhan spesifik mereka, kembangkan jembatan di antara mereka semua dan berdasarkan hal itu pahami target organisasi 
tahun ini. Jika Anda memiliki pemahaman yang jelas tentang visi bisnis, Anda juga akan dapat mengembangkan budaya yang akan membantu mencapai target yang ditetapkan dengan mudah dan dengan kecepatan yang lebih cepat (Sondhi, 2018).

\section{Memahami Asuransi Kesehatan}

Salah satu bagian terbesar dari paket kompensasi adalah asuransi kesehatan. Manajemen SDM adalah wajah dari program itu untuk karyawan. Ya, perusahaan asuransi itu sendiri akan dengan senang hati membantu karyawan, tetapi Anda perlu pemahaman yang kuat tentang bagaimana berbagai rencana bekerja untuk membantu karyawan dengan manfaat mereka. Jika Anda seorang manajer SDM tingkat senior, Anda akan memainkan peran kunci dalam memilih rencana perusahaan Anda. Dalam hal ini, Anda akan membutuhkan lebih dari sekadar pemahaman di tingkat permukaan tentang bagaimana perawatan kesehatan dan manfaat lainnya bekerja (Lucas, 2019). 


\section{References}

Alexander, M. (2019). 5 HR Management Tips to Improve Team Performance. Retrieved June 2, 2019, from https://www.techrepublic.com/article/5-hrmanagement-tips-to-improve-teamperformance/

Asitah, N., Maula, I., Munjidah, A., Nahdiyah,

K., Yuniarti, D., Sholichah, S. A., Purnomo, A., Rosyidah, E., Anam, F., Achmadi, A.K., \& Fahmi, M. (2018, May 25). Urgensi Aktualisasi Manajemen Sumber Daya Manusia untuk Resurgensi Perekonomian di Sidoarjo. http://doi.org/10.17605/OSF.IO/TG79P

Lucas, S. (2019). 10 Skills Every HR Manager Needs to Succeed. Retrieved May 28, 2019, from https://www.thebalancecareers.com/skillshr-managers-need-to-succeed-4138124

Mulholland, B. (2017). 12 HR Management Tips to Run an Effective Business (and Prevent Total Chaos). Retrieved June 1, 2019, from https://www.process.st/hrmanagement-tips/ 
Nahdiyah, K., Amrina, S., Purnomo, A., \& Rosyidah, E. (2017). SD Taman

Pendidikan Islam Porong Iman Kuat Bekal di Akhirat. In Wirausaha Pendidikan Indonesia (Jilid 2). Sidoarjo: Unusida Press.

Purnomo, A., Putri, R. A., \& Rosyidah, E. (2017). Kamus Manajemen Sumber Daya Manusia. Sidoarjo: UNUSIDA Press.

Sondhi, P. (2018). Be an Outstanding HR Professional with these 7 Tips. Retrieved May 27, 2019, from https://www.entrepreneur.com/article/3128 94

Vulpen, E. van. (2018). 7 Human Resource Best Practices (A mini-guide to HRM). Retrieved June 4, 2019, from https://www.digitalhrtech.com/humanresource-best-practices/ 